\title{
Analisis Kinerja Anggaran Belanja pada Badan Pengelola Keuangan dan Barang Milik Daerah Provinsi Sulawesi Utara
}

\author{
oleh: \\ Chrisman Youlli Karinda \\ Vantje Ilat \\ Lidia Mawikere
}

\begin{abstract}
ABSTRAK
Belanja dalam Laporan Realisasi Anggaran Merupakan Komponen penting yang mengundang perhatian publik. Hal itu disebabkan karena masyarakat sebagai pemberi dana melalui pajak daerah yang mereka bayarkan berkepentingan untuk mengetahui apakah dana tersebut telah digunakan dengan semestinya, efisien, efektif, dan berorientasi pada kepentingan publik. Adapun tujuan dari penelitian ini adalah untuk mengetahui dan menganalisis kinerja anggaran belanja dalam laporan realisasi anggaran pada Badan Pengelola Keuangan Dan Barang Milik Daerah Provinsi Sulawesi Utara dari Tahun Anggaran 2009-2012. Data yang digunakan adalah Laporan Realisasi Anggaran Tahun Anggaran 2009-2012. Dari hasil analisis yang terdiri dari analisis varians (selisih) belanja, analisis pertumbuhan belanja, analisis keserasian belanja, rasio efisiensi belanja dan rasio belanja daerah terhadap PDRB. Tahun 2009 terdapat selisih anggaran belanja sebesar Rp. 95.735.271.217,62, tahun 2010 Rp. 61.329.077.260,00, tahun 2011 Rp. 157.837.732.725,00, tahun 2012 Rp. 189.330.495.775,00. Tahun 2010 terjadi pertumbuhan realisasi belanja sebesar 9,96\% dibanding tahun sebelumnya, tahun 2011 sebanyak 13,05\%, tahun 2012 sebanyak 37,74\%. Untuk analisis keserasian belanja, tahun 2012 rasio belanja operasi sebesar 69,013\%, rasio belanja modal sebesar 19,795\%, rasio belanja tak terduga $0,004 \%$, rasio transfer bagi hasil 11,188\%. Tahun 2009 realisasi belanja sebesar 91,53\% dari yang dianggarkan, tahun 2010 hanya sebesar 94,88\%, tahun 2011 hanya sebesar 89,07\%, tahun 2012 hanya sebesar $90,34 \%$.
\end{abstract}

Kata kunci : kinerja, anggaran, belanja.

Actual expenditure in the Budget Statement is an important component of inviting public attention. That's because society as a conduit of funds through local taxes they pay interest to know whether these funds have been used properly, efficiently, effectively, and public interest-oriented. The purpose of this study is to investigate and analyze the performance of the budget in the budget realization report on Financial Management Board and District Property North Sulawesi province of Fiscal Year 2009-2012. The data used are the Actual Budget Report for Fiscal Year 2009-2012. From the results of the analysis consisted of analysis of variance (difference) shopping, spending growth analysis, analysis of expenditure harmony, efficiency ratio and the ratio of spending to GDP shopping areas. In 2009 there is a difference in the budget of Rp . 95, 735,271,217.62, in 2010 USD . 61,329,077,260.00, in 2011 USD . 157,837,732,725.00, in 2012 USD . 189,330,495,775.00 . In 2010 there is a growth of $9.96 \%$ expenditure over the previous year, the year 2011 of $13.05 \%$, in 2012 as much as $37.74 \%$. For compatibility analyzes expenditure, operating expenditure ratio in 2012 was $69.013 \%$, the ratio of capital expenditure of $19.795 \%$, the ratio of unforeseen expenditures $0.004 \%$ , the ratio of the transfer of $11.188 \%$ profit sharing. Expenditures in 2009 amounted to $91.53 \%$ of the budgeted, in 2010 only amounted to $94.88 \%$, in 2011 only amounted to $89.07 \%$, in 2012 only amounted to $90.34 \%$.

Keywords : performance, budget, expenditure. 


\section{PENDAHULUAN \\ Latar Belakang}

Untuk mewujudkan otonomi daerah yang efektif. Maka pada tahun 1999 pemerintah melakukan reformasi dibidang Pemerintahan Keuangan Daerah dan Pengelolaan Keuangan daengan ditetapkannya Undang-Undang Nomor 22 Tahun 1999 tentang Pemerintah Daerah dan UndangUndang Nomor 25 tahun 1999 tentang Perimbangan Keuangan antara Pemerintah Pusat dan Daerah. Kedua Undang-Undang tersebut membawa perubahan fundamental dalam hubungan Tata Pemerintahan dan Pengelolaan Keuangan Daerah. (Darise 2008: 1)

Laporan Realisasi Anggaran (LRA) yang dipublikasikan pemerintah daerah memberikan informasi yang sangat bermanfaat untuk menilai kinerja keuangan daerah. Jika dibandingkan dengan neraca LRA menduduki prioritas yang lebih penting, dan LRA ini merupakan jenis laporan keuangan daerah yang dahulu dihasilkan sebelum membuat laporan neraca dan laporan arus kas. Anggaran dalam pemerintahan merupakan tulang punggung (backbone) penyelenggaraan pemerintahan. Anggaran memiliki peran penting sebagai alat stabilisasi, distribusi, alokasi sumber daya publik, perencanaan dan pengendalian organisasi serta penilaian kinerja. Oleh karena itu LRA menjadi salah satu laporan pertanggungjawaban keuangan daerah yang utama. Berdasarkan LRA tersebut pembaca laporan dapat membuat analisis kinerja laporan keuangan berupa analisis pendapatan, analisis belanja, dan analisis pembiayaan. (Mahmudi 2010: 135)

Belanja dalam Laporan Realisasi Anggaran merupakan komponen penting yang mengundang perhatian publik. Hal itu disebabkan karena masyarakat sebagai pemberi dana publik (publik fund) melalui pajak daerah yang mereka bayarkan berkepentingan untuk mengetahui apakah dana tersebut telah digunakan dengan semestinya, efisien, efektif, dan berorientasi pada kepentingan publik. Belanja daerah tersebut juga mencerminkan kebijakan menghasilkan pendapatan merupakan suatu hal yang lebih sulit dibandingkan membelanjakan. Kaeran sifat belanja yang relatif mudah dilakukan dan rentan akan terjadinya inefisiensi dan kebocoran, maka perencanaan, pengendalian dan pengewasan terhadap belanja sangat penting dilakukan. Setelah dibelanjakan dan dilaporkan dalam Laporan Realisasi Anggaran, analisis terhadap belanja ini pun mutlak harus dilakukan untuk dijadikan dasar evaluasi, koreksi dan perbaikan ke depan. (Mahmudi 2010: 155)

Objek penelitian dalam skripsi ini adalah Badan Pengelolaan Keuangan dan Barang Milik Daerah Provinsi Sulawesi Utara. BPK-BMD Prov. Sulawesi Utara dipilih sebagai objek karena merupakan unsur pendukung tugas Gubernur yang mempunyai tugas melaksanakan penyusunan dan pelaksanaan kebijakan daerah yang bersifat spesifik di bidang pengelolaan keuangan dan barang milik daerah serta BPK-BMD menyajikan laporan keuangan secara umum dari Pemerintah Provinsi Sulawesi Utara.

\section{Tujuan Penelitian}

Tujuan penelitian ini adalah untuk mengetahui dan menganalisis kinerja anggaran belanja pada Badan Pengelola Keuangan Dan Barang Milik Daerah Provinsi Sulawesi Utara dari Tahun Anggaran 2009-2012.

\section{TINJAUAN PUSTAKA}

\section{Akuntansi}

SAP 2010 (2011: 4) menyatakan akuntansi adalah proses identifikasi, pencatatan, pengukuran, klasifikasian, pengikhtisaran transaksi dan kejadian keuangan, penyajian laporan serta penginterprestasian atas hasilnya.

Horngren, et al (2009: 2) menyatakan akuntansi adalah sistem informasi yang mengukur kegiatan usaha, memproses data menjadi laporan, dan mengkomunikasikan hasilnya ke pengambil keputusan.

\section{Akuntansi Pemerintahan}


Mardiasmo (2009: 1) menyatakan Akuntansi sektor publik memiliki kaitan yang erat dengan penerapan dan perlakuan akuntansi pada domain publik. Domain publik sendiri memiliki wilayah yang lebh luas dan kompleks dibandingkan dengan sektor swasta. Keleluasan wilayah publik tidak hanya disebabkan luasnya jenis dan bentuk organisasi yang berada di dalamnya, akan tetapi juga karena kompleksnya lingkungan yang mempengaruhi lembaga-lembaga publik tersebut. Secara kelembagaan, domai publik antara lain meliputi badan-badan pemerintahan (pemerintah pusat dan daerah serta unit kerja pemerintah), perusahaan milik negara (BUMN dan BUMD), yayasan, organisasi politik dan organisasi massa, Lembaga Swadaya Masyarakat (LSM), Universitas, dan organisasi nirlaba lainnya. Sektor publik bersifat heterogen dan dipengaruhi oleh faktor-faktor.

\section{Akuntansi Belanja}

Belanja adalah semua pengeluaran dari Rekening Kas Umum Negara/Daerah yang mengurangi Saldo Anggaran Lebih dalam periode tahun anggaran bersangkutan yang tidak akan diperoleh pembayarannya kembali oleh pemerintah. SAP 2010 (2011: 331) menyatakan Belanja diakui pada saat terjadinya pengeluaran dari Rekening Kas Umum Negara/Daerah. Halim (2007: 102) memberikan definisi belanja menurut basis kas adalah semua pengeluaran oleh bendahara umum negara/daerah yang mengurangi ekuitas dana jangka pendek dalam periode tahun anggaran bersangkutan yang tidak akan diperoleh pembayarannya kembali oleh pemerintah. Sedangkan menurut basis akrual, belanja merupakan kewajiban pemerintah yang diakui sebagai pengurang nilai kekayaan bersih. Darise (2008: 99) menyatakan Belanja diklafikasikan menurut klasifikasi ekonomi (jenis belanja), organisasi, dan fungsi.

\section{Kedudukan Belanja Daerah Dalam APBD.}

Kedudukan belanja dalam APBD, Yakni:

a. Merupakan kewajiban daerah yang diakui sebagai pengurang nilai kekayaan bersih dalam periode tahun anggaran yang bersangkutan.

b. Belanja daerah disusun berdasarkan pendekatan anggaran serta berorientasi pada pencapaian hasil dari input yang direncanakan. Hal tersebut bertujuan meningkatkan akuntabilitas perencanaan anggaran serta memperjelas efektivitas dan efisiensi penggunaan alokasi anggaran yang dimaksud.

c. Penyusunan belanja daerah diprioritaskan untuk menunjang efektifitas pelaksanaan tugas dan fungsi masing-masing satuan kerja perangkat daerah (SKPD) dalam rangka melaksanakan kewajiban daerah yang menjadi tanggung jawabnya. (DJPK, 2013: 96)

\section{Laporan Realisasi Anggaran}

SAP 2010 (2011: 31) menyatakan Laporan Realisasi Anggaran menyajikan ikhtisar sumber, alokasi, dan pemakaian sumber daya keuangan yang dikelola oleh pemerintah pusat/daerah, yang menggambarkan perbandingan antara anggaran dan realisasinya dalam satu periode pelaporan.

\section{Tujuan Laporan Realisasi Anggaran}

SAP 2010 (2011: 91) menyatakan Tujuan standar Laporan Realisasi Anggaran adalah menetapkan dasar-dasar penyajian Laporan Realisasi Anggaran untuk pemerintah dalam rangka memenuhi tujuan akuntabilitas sebagaimana ditetapkan oleh peraturan perundang-undangan.

Lebih lanjut lagi tujuan pelaporan realisasi anggaran adalah memberikan informasi realisasi dan anggaran entitas pelaporan. Perbandingan antara anggaran dan realisasinya menunjukan tingkat ketercapaian target-target yang telah disepakati antara legislatif dan eksekutif sesuai dengan peraturan perundang-undangan.

\section{Manfaat Informasi Realisasi Anggaran}

SAP 2010 (2011: 92) Laporan Realisasi Anggaran menyediakan informasi mengenai realisasi pendapatan-LRA, belanja, transfer, surplus/deficit-LRA, dan pembiayaan dari suatu entitas pelaporan yang masing-masing diperbandingkan dengan anggarannya. Informasi tersebut berguna bagi para pengguna laporan dalam mengevaluasi keputusan mengenai alokasi sumber-sumber daya ekonomi, akuntabilitas dan ketaatan entitas pelaporan terhadap anggaran dengan: 
a. Menyediakan informasi mengenai sumber, alokasi, dan penggunaan sumber daya ekonomi;

b. Menyediakan informasi mengenai realisasi anggaran secara menyeluruh yang berguna dalam mengevaluasi kinerja pemerintah dalam hal efesiensi dan efektivitas penggunga anggaran.

\section{Kinerja Anggaran Belanja}

Mahsun (2009: 25) Kinerja (performance) adalah gambaran mengenai tingkat pencapai pelaksanaan suatu kegiatan/program/kebijakan dalam mewujudkan sasaran, tujuan, misi dan visi organisasi yang tertuang dalam strategic planning suatu organisasi. Istilah kinerja sering digunakan untuk menyebut prestasi atau tingkat keberhasilan individu maupun kelompok individu. Kinerja bisa diketahui hanya jika individu atau kelompok individu tersebut mempunyai kriteria keberhasilan yand telah ditetapkan. Kriteria keberhasilan ini berupa tujuan-tujuan atau target-target tertentu yang hendak dicapai. Tanpa ada tujuan atau target, kenerja seseorang atau organisasi tidak mungkin dapat diketahui karena tidak ada tolok ukurnya.

Mahmudi (2010: 156) menyatakan berdasarkan informasi pada Laporan Realisasi Anggaran, kita dapat membuat analisis anggaran khususnya analisis belanja antara lain berupa :

a. Analisis Varians Belanja.

Analisis varians merupakan analisis terhadap perbedaan atau selisis antara realisasi belanja dengan anggaran. Berdasarkan Laporan Realisasi Anggaran yang disajikan, pembaca laporan dapat mengetahui secara langsung besarnya varians anggaran dengan realisasinya yang bisa dinyatakan dalam bentuk nilai nominalnya atau persentasenya.Selisih anggaran belanja dikategorikan menjadi dua jenis, yaitu 1) Selisih disukai (favourable variance) dan 2) selisih tidak disukai (unfavourable variance). Dalam hal realisasi belanja lebih kecil dari anggarannya maka disebut favourable variance, sedangkan jika realisasi belanja lebih besar dari anggarannya maka dikategorikan unfavourable variance.

b. Analisis Pertumbuhan Belanja.

Analisis pertumbuhan belanja bermanfaat untuk mengetahui pertumbuhan belanja dari tahun ke tahun positif atau negatif. Pada umumnya belanja memiliki kecenderungan selalu naik. Alasan kenaikan belanja biasanya dikaitkan dengan penyesuaian terhadap inflasi, perubahan kurs rupiah, perubahan jumlah cakupan layanan, dan penyesuaian faktor makro ekonomi. Pertumbuhan belanja harus diikuti dengan pertumbuhan pendapat yang seimbang

c. Analisis Keserasian Belanja.

Analisis keserasian belanja bermanfaat untuk mengetahui keseimbangan antarbelanja. Hal ini terkait dengan fungsi anggaran sebagai alat distribusi, allokasi, dan stabilisasi. Agar fungsi anggaran tersebut berjalan dengan baik, maka pemerintah daerah perlu membuat harmonisasi belanja. Analisis keserasian belanja antara lain berupa:

1) Analisis Belanja per Fungsi terhadap Total Belanja.

Analisis belanja per fungsi terhadap total belanja dihitung dengan cara membandingkan belanja tiap-tiap dungsi terhadap total belanja dalam APBD.

2) Analisis Belanja Operasi terhadap Total Belanja.

Analisis belanja operasi terhadap total belanja merupakan perbandingan antara total belanja operasi dengan total belanja daerah. Rasio ini menginformasikan mengenai porsi belanja daerah yang dialokasikan untuk belanja opersasi. Belanja operasi merupakan belanja yang manfaatnya habis dikonsumsi dalam satu tahun anggaran, sehingga belanja operasi sifatnya jangka pendek dan dalam hal tertentu sifatnya rutin atau berulang.

3) Analisis Belanja Modal terhadap Total Belanja.

Analisis Belanja Modal terhadap Total Belanja merupakan perbandingan antara total reallisasi belanja modal dengan total belanja daerah. Berdasarkan rasio ini, pembaca laporan dapat mengetahui porsi belanja daerah yang dialokasikan untuk investasi dalam bentuk belanja modal pada tahun anggaran bersangkutan. Berbeda dengan belanja operasi yang besifat jangka pendek 
dan rutin, pengeluaran belanja modal yang dilakukan saat ini akan memberikan manfaat jangka menengah dan panjang.

4) Analisis Belanja Langsung dan Tidak Langsung.

Analisis proporsi belanja langsung dan tidak langsung bermanfaat untuk kepentingan manajemen internal pemerintah daerah, yaitu untuk pengendalian biaya dan pengendalian anggaran. Belanja langsung dan tidak langsung biasanya tidak menjadi bagian dari laporan keuangan eksternal, namun informasi tersebut sangat penting bagi manajemen internal.

d. Rasio Efisiensi Belanja.

Rasio efesiensi belanja merupakan perbandingan antara realisasi belanja dengan anggaran belanja. Rasio efesiensi belanja ini digunakan untuk mengukur tingkat penghematan anggaran yang dilakukan pemerintah. Angka yang dihasikan dari rasio efisiensi ini tidak bersifat absolut, tetapi relatif. Artinya tidak ada standar baku yang dianggap baik untuk rasio ini. Kita hanya dapat mengatakan bahwa tahun ini belanja pemerintah daerah relatif lebih efisien dibandingkan tahun lalu. Pemerintah daerah dinilai telah melakukan efisiensi anggaran jika rasio efisiensinya kurang dari 100\%. Sebaliknya jika melebihi 100\% maka mengindikasikan terjadinya pemborosan anggaran.

e. Rasio Belanja Daerah Terhadap PDRB.

Rasio belanja daerah terhadap Product Domestic Regional Bruto (PDRB) merupakan perbandingan antara total belanja daerah dengan PDRB yang dihasilkan daerah. Rasio ini menunjukan produktivitas dan efektivitas belanja daerah.

Penelitian Terdahulu.

Tabel 1. Penelitian Terdahulu

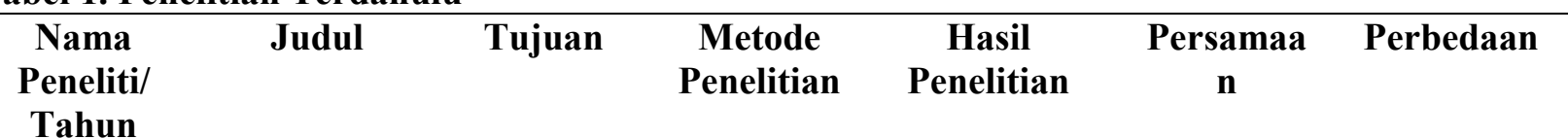

\begin{tabular}{|c|c|c|c|c|c|c|}
\hline $\begin{array}{l}\text { Galaento/ } \\
2010\end{array}$ & $\begin{array}{l}\text { Analisis } \\
\text { Kinerja } \\
\text { Belanja } \\
\text { Dalam } \\
\text { Laporan } \\
\text { Realisasi } \\
\text { Anggaran } \\
\text { (LRA) Pada } \\
\text { Dinas } \\
\text { Pendapatan } \\
\text { Pengelolaa } \\
\text { n Keuangan } \\
\text { Dan Aset } \\
\text { Daerah Di } \\
\text { Kabupaten } \\
\text { Luwuk } \\
\text { Banggai. }\end{array}$ & $\begin{array}{l}\text { Untuk } \\
\text { mengetahui } \\
\text { kinerja } \\
\text { belanja } \\
\text { dalam LRA } \\
\text { pada Dinas } \\
\text { PPKAD di } \\
\text { kabupaten } \\
\text { Luwuk } \\
\text { Banggai dari } \\
\text { Tahun } \\
\text { Anggaran } \\
\text { (TA) 2007- } \\
\text { 2010. }\end{array}$ & $\begin{array}{l}\text { Deskriptif } \\
\text {. }\end{array}$ & $\begin{array}{l}\text { Kinerja } \\
\text { belanja Dinas } \\
\text { PPKAD Di } \\
\text { Kabupaten } \\
\text { Luwuk } \\
\text { Banggai } \\
\text { terhadap } \\
\text { Laporan } \\
\text { Keuangan } \\
\text { adalah baik. }\end{array}$ & $\begin{array}{l}\text { Meneliti } \\
\text { Kinerja } \\
\text { belanja } \\
\text { dalam } \\
\text { Laporan } \\
\text { Realisasi } \\
\text { Anggaran. }\end{array}$ & $\begin{array}{l}\text { Pada objek } \\
\text { penelitian. }\end{array}$ \\
\hline
\end{tabular}




\begin{tabular}{|c|c|c|c|c|c|c|}
\hline $\begin{array}{l}\text { Marizka/200 } \\
9\end{array}$ & $\begin{array}{l}\text { Analisis } \\
\text { Kinerja } \\
\text { Pengelolaa } \\
\text { n Anggaran } \\
\text { Pendapatan } \\
\text { Dan } \\
\text { Belanja } \\
\text { Daerah } \\
\text { Pemerintah } \\
\text { Kota } \\
\text { Medan. }\end{array}$ & $\begin{array}{l}\text { Untuk } \\
\text { mengetahui } \\
\text { dan } \\
\text { menganalisi } \\
\text { s kinerja } \\
\text { anggaran } \\
\text { pendapatan, } \\
\text { belanja dan } \\
\text { pembiayaan } \\
\text { Kota Medan } \\
\text { selama } \\
\text { periode } \\
\text { 2003-2007. }\end{array}$ & Deskriptif & $\begin{array}{l}\text { Menunjukan } \\
\text { bahwa } \\
\text { Pemerintah } \\
\text { Kota Medan } \\
\text { dalam } \\
\text { merealisasika } \\
\text { n pajak } \\
\text { daerah, } \\
\text { pertumbuhan } \\
\text { pendapatan, } \\
\text { anggaran } \\
\text { belanja dan } \\
\text { pembiayaan } \\
\text { pada tahun } \\
\text { 2003-2007 } \\
\text { dapat di sudah } \\
\text { baik. }\end{array}$ & $\begin{array}{l}\text { Meneliti } \\
\text { Kinerja } \\
\text { anggaran } \\
\text { belanja } \\
\text { dalam } \\
\text { Laporan } \\
\text { Relisasi } \\
\text { Anggaran. }\end{array}$ & $\begin{array}{l}\text { Pada objek } \\
\text { penelitian } \\
\text { dan } \\
\text { menganalisi } \\
\text { s kinerja } \\
\text { anggaran } \\
\text { pendapatan } \\
\text { dan } \\
\text { pembiayaan. }\end{array}$ \\
\hline
\end{tabular}

\section{METODE PENELITIAN \\ Jenis Penelitian}

Jenis penelitian yang dilakukan adalah penelitian deskriptif. Erlina (2007: 64) menyatakan Penelitian Deskriptif adalah penelitian terhadap fenomena atau populasi tertentu yang diperoleh oleh peneliti dari subjek beberapa individu, organisasional, industri atau perspektif lain.

\section{Metode Pengumpulan Data}

Data adalah sekumpulan informasi yang diperlukan untuk pengambilan keputusan. Data diperoleh dengan mengukur nilai satu atau lebih variabel dalam sampel (atau populasi) (Kuncoro 2009:145).

Sumber data yang digunakan dalam penelitian ini adalah data primer yang diperoleh melalui wawancara dengan Kepala Sub Bagian Hukum dan Kepegawaian yang lalu disposisi ke Kepala Bidang Akuntansi yang lalu didisposisi lagi ke Kepala Sub Bagian Bidang Pelaporan Keuangan.

\section{Metode Analisis}

Metode analisis dalam penelitian ini adalah dengan menggunakan metode analisis deskriptif yang didasarkan pada penggambaran yang mendukung analisa tersebut, analisis ini menekankan pada pemahaman mengenai masalah-masalah dalam kehidupan sosial berdasarkan kondisi realitas atau natural setting yang holistis, kompleks, dan rinci yang sifatnya menjelaskan secara uraian atau bentuk kalimat.

Adapun metode analisis dalam penelitian ini menggunakan alat analisis kinerja belanja (Mahmudi, 2010: 156):

a. Analisis Varians Belanja (Selisih Belanja)

Analisis Varians Belanja = Realisasi Belanja - Anggaran Belanja

b. Analisis Pertumbuhan Belanja.

Pertumbuhan Belanja $\mathrm{Thn}_{\mathrm{t}}=$ Belanja $\mathrm{Thn}_{\mathrm{t}}-$ Belanja $\mathrm{Thn}_{\mathrm{t}-1} \times 100 \%$

Realisasi Belanja Thn $_{t-1}$

c. Analisis Keserasian Belanja.

1) Analisis Belanja Operasi terhadap Total Belanja.

Rasio Belanja Operasi Terhadap Belanja $=\underline{\text { Total Belanja Operasi } \times 100 \%}$

\section{Total Belanja}

2) Analisis Belanja Modal terhadap Total Belanja. 
Rasio Belanja Modal Terhadap Belanja $=\underline{\text { Total Belanja Modal } \times 100 \% ~}$

Total Belanja

3) Analisis Belanja Belanja Tak Terduga Terhadap Total Belanja.

Rasio Belanja Tak Terduga Terhadap Belanja $=$ Total Belanja Tak Terduga $\times 100 \%$

Total Belanja

4) Analisis Belanja Transfer Bagi Hasil Ke Kab/Kota Terhadap Total Belanja.

Rasio Belanja Transfer Bagi Hasil Terhadap Belanja = Total Transfer Bagi Hasil x 100\%

Total Belanja

d. Rasio Efesiensi Belanja.

Rasio Efisiensi Belanja $=$ Realisasi Belanja $\quad x 100 \%$

Anggaran Belanja

e. Rasio Belanja Daerah Terhadap PDRB.

Rasio Belanja Daerah thd PDRB $=$ Total Realisasi Anggaran $\times 100 \%$

Total PDRB

HASIL PENELITIAN DAN PEMBAHASAN

Analisis Varians (Selisih) Anggaran Belanja

Analisis varians merupakan analisis terhadap perbedaan atau selisis antara realisasi belanja dengan anggaran (Mahmudi 2010: 157).

Analisis Varians Belan ja = Realisasi Belanja - Anggaran Belanja

Tabel 2. Analisis Varians Belanja T.A 2009-2012

\begin{tabular}{ccccc}
\hline $\begin{array}{c}\text { Tahu } \\
\mathbf{n}\end{array}$ & Realisasi & Anggaran & Selisih & $\begin{array}{c}\text { Persentas } \\
\mathbf{e} \\
\mathbf{( \% )}\end{array}$ \\
\hline 2009 & $1.034 .427 .881 .782,3$ & 1.130 .163 .153 .000$, & $-95.735 .271 .217,62$ & 8,47 \\
2010 & $\begin{array}{c}1.137 .423 .444 .598,0 \\
0\end{array}$ & $\begin{array}{c}1.198 .752 .521 .858, \\
00\end{array}$ & $-61.329 .077 .260,00$ & 5,12 \\
2011 & $1.285 .864 .832 .396,0$ & 1.443 .702 .565 .121$, & - & $157.837 .732 .725,0$ \\
& 0 & 00 & 0 & \\
2012 & $1.771 .118 .335 .760,0$ & 1.960 .448 .831 .535$, & - & $189.330 .495 .775,0$ \\
& 0 & 00 & 0 & 9,66 \\
\hline
\end{tabular}

Sumber : BPK-BMD Prov. Sulawesi Utara (Data Diolah)

Analisis Pertumbuhan Belanja

Analisis pertumbuhan belanja bermanfaat untuk mengetahui perkembangan belanja dari tahun ke tahun (Mahmudi 2010: 160).

PertumbuhanBelanjaThn $_{\mathrm{t}}=\frac{\text { Realisasi BelanjaThn }_{\mathrm{t}}-\text { Realisasi Belan jaThn }_{\mathrm{t}-1}}{\text { RealisasiBelanjaThn }_{\mathrm{t}-1}} \times 100 \%$

Tabel 3. Pertumbuhan Belanja T.A 2010

\begin{tabular}{rrrrr} 
Uraian & Realisasi Belanja & & \multicolumn{2}{c}{ Realisasi Belanja } \\
\cline { 3 - 5 } & Tahun 2010 & Tahun 2009 & $\begin{array}{c}\text { Kenaikan } \\
\text { (Penurunan) }\end{array}$ & \% \\
\hline \multirow{2}{*}{ BELANJA } & 1.137 .423 .444 .59 & 1.034 .427 .881 .78 & $102.995 .562 .815,6$ & \multirow{2}{*}{9,96} \\
& 8,00 & 2,38 & 2 &
\end{tabular}




\begin{tabular}{|c|c|c|c|c|}
\hline $\begin{array}{l}\text { BELANJA } \\
\text { OPERASI }\end{array}$ & $\begin{array}{r}834.664 .774 .536, \\
00\end{array}$ & $\begin{array}{r}654.202 .481 .496 \\
38\end{array}$ & $\begin{array}{r}180.462 .293 .039,6 \\
2\end{array}$ & 27,59 \\
\hline ELANJA & 164.360.062.551, & 241.283.649.548, & $(76.923 .586 .997,00$ & $(31,88$ \\
\hline MODAL & 00 & 00 & ) & ) \\
\hline $\begin{array}{l}\text { BELANJA TAK } \\
\text { TERDUGA }\end{array}$ & $1.298 .176 .216,00$ & $2.253 .858 .320,00$ & $(955.682 .104,00)$ & $(42,40$ \\
\hline TRANSFER & $\begin{array}{r}137.100 .431 .295, \\
00\end{array}$ & $\begin{array}{r}136.687 .892 .418 \\
00\end{array}$ & $412.538 .877,00$ & 0,30 \\
\hline
\end{tabular}

Sumber : BPK-BMD Prov. Sulawesi Utara (Data Diolah)

Tabel 4. Pertumbuhan Belanja T.A 2011

\begin{tabular}{lrrrr}
\hline \multirow{2}{*}{ Uraian } & $\begin{array}{c}\text { Realisasi Belanja } \\
\text { Tahun 2011 }\end{array}$ & $\begin{array}{c}\text { Realisasi Belanja } \\
\text { Tahun 2010 }\end{array}$ & \multicolumn{2}{c}{ Pertumbuhan } \\
\cline { 4 - 6 } & & & Kenaikan & (Penurunan) \\
\hline BELANJA & 1.285 .864 .832 .39 & 1.137 .423 .444 .59 & $148.441 .387 .798,0$ & 13,05 \\
BELANJA & 6,00 & 8,00 & 0 & \\
OPERASI & 863.895 .537 .064$, & 834.664 .774 .536$, & $29.230 .762 .528,00$ & 3,50 \\
BELANJA & 00 & 00 & & \\
MODAL & 233.630 .332 .387$, & 164.360 .062 .551$, & $69.270 .269 .836,00$ & 42,15 \\
BELANJA TAK & 00 & 00 & & $(38,43$ \\
TERDUGA & $799.238 .460,00$ & $1.298 .176 .216,00$ & $(498.937 .756,00)$ & ) \\
TRANSFER & 187.539 .904 .485$, & 137.100 .431 .295$, & $50.439 .473 .190,00$ & 36,79 \\
\hline
\end{tabular}

Sumber : BPK-BMD Prov. Sulawesi Utara (Data Diolah)

Tabel 5. Pertumbuhan Belanja T.A 2012

\begin{tabular}{|c|c|c|c|c|}
\hline \multirow{2}{*}{ Uraian } & \multirow{2}{*}{$\begin{array}{l}\text { Realisasi Belanja } \\
\text { Tahun } 2012\end{array}$} & \multirow{2}{*}{$\begin{array}{l}\text { Realisasi Belanja } \\
\text { Tahun } 2011\end{array}$} & \multicolumn{2}{|c|}{ Pertumbuhan } \\
\hline & & & $\begin{array}{c}\text { Kenaikan } \\
\text { (Penurunan) }\end{array}$ & $\%$ \\
\hline BELANJA & $\begin{array}{r}1.771 .118 .335 .760 \\
00\end{array}$ & $\begin{array}{r}1.285 .864 .832 .39 \\
6,00\end{array}$ & $\begin{array}{r}485.253 .503,364 \\
, 00\end{array}$ & 37,74 \\
\hline BELANJA & 1.222.295.084.408, & 863.895.537.064, & $\begin{array}{r}358.399 .547 .344 \\
\end{array}$ & 41,49 \\
\hline $\begin{array}{l}\text { OPERASI } \\
\text { BELANJA }\end{array}$ & $\begin{array}{r}00 \\
350.596 .718 .100,0\end{array}$ & $\begin{array}{r}00 \\
233.630 .332 .387\end{array}$ & $\begin{array}{r}, 00 \\
116.966 .385 .713\end{array}$ & \\
\hline MODAL & 0 & 00 &, 00 & 50,06 \\
\hline $\begin{array}{l}\text { BELANJA TAK } \\
\text { TERDUGA }\end{array}$ & $70.120 .000,00$ & $799.238 .460,00$ & $\begin{array}{r}(729.118 .460,00 \\
)\end{array}$ & $\begin{array}{c}(91,23 \\
)\end{array}$ \\
\hline TRANSFER & $\begin{array}{r}198.156 .413 .252,0 \\
0\end{array}$ & $\begin{array}{r}187.539 .904 .485 \\
00\end{array}$ & $\begin{array}{r}10.616 .508 .767 \\
00\end{array}$ & 5,66 \\
\hline
\end{tabular}

Sumber : BPK-BMD Prov. Sulawesi Utara (Data Diolah)

Analisis Keserasian Belanja

Analisis keserasian belanja bermanfaat untuk mengetahui keseimbangan antarbelanja.Hal ini terkait dengan fungsi anggaran sebagai alat distribusi, alokasi, dan stabilisasi (Mahmudi 2010: 162).

a. Analisis Belanja Operasi Terhadap Total Belanja 
Analisis belanja operasi terhadap total belanja merupakan perbandingan antara total realisasi belanja operasi dengan total belanja. Rasio ini memberikan informasi mengenai porsi belanja daerah yang dialokasikan untuk belanja operasi pada tahun anggaran bersangkutan (Mahmudi 2010: 164).

$$
\text { Rasio Belanja Operasi Terhadap Belanja }=\frac{\text { Total Belan ja Operasi }}{\text { Total Belanja }} \times 100 \%
$$

Tabel 6. Analisis Belanja Operasi Terhadap Total Belanja T.A 2009-2012

\begin{tabular}{crcc}
\hline $\begin{array}{c}\text { Tahun } \\
\text { Anggaran }\end{array}$ & $\begin{array}{c}\text { Total Belanja } \\
\text { Operasi (RP) }\end{array}$ & Total Belanja (RP) & $\begin{array}{c}\text { Rasio Belanja } \\
\text { Operasi } \\
\text { terhadap Total } \\
\text { Belanja (\%) }\end{array}$ \\
\hline 2009 & $654.202 .481 .496,38$ & $1.034 .427 .881 .782,38$ & 63,24 \\
2010 & $834.664 .774 .536,00$ & $1.137 .423 .444 .598,00$ & 73,38 \\
2011 & $863.895 .357 .064,00$ & $1.285 .864 .832 .396,00$ & 67,18 \\
2012 & $1.222 .295 .084 .408,00$ & $1.771 .118 .335 .760,00$ & 69,013 \\
\hline
\end{tabular}

Sumber : BPK-BMD Prov. Sulawesi Utara (Data Diolah)

b. Analisis Belanja Modal Terhadap Total Belanja

Analisis belanja modal terhadap total belanja merupakan perbandingan antara total realisasi belanja modal dengan total belanja. Rasio ini memberikan informasi mengenai porsi belanja daerah yang dialokasikan untuk belanja modal pada tahun anggaran bersangkutan (Mahmudi 2010: 164).

$$
\text { Rasio Belanja Modal Terhadap Belanja }=\frac{\text { Total Belanja Modal }}{\text { Total Belanja }} \times 100 \%
$$

Tabel 7. Analisis Belanja Modal Terhadap Total Belanja T.A 2009-2012

\begin{tabular}{cccc}
$\begin{array}{c}\text { Tahun } \\
\text { Anggaran }\end{array}$ & $\begin{array}{c}\text { Total Belanja } \\
\text { Modal (RP) }\end{array}$ & Total Belanja (RP) & $\begin{array}{c}\text { Rasio Belanja } \\
\text { Modal terhadap } \\
\text { Total Belanja } \\
\mathbf{( \% )}\end{array}$ \\
\hline 2009 & $241.283 .649 .54,00$ & $1.034 .427 .881 .782,38$ & 23,33 \\
2010 & $164.360 .062 .551,00$ & $1.137 .423 .444 .598,00$ & 14,45 \\
2011 & $233.630 .332 .387,00$ & $1.285 .864 .832 .396,00$ & 18,17 \\
2012 & $350.596 .718 .100,00$ & $1.771 .118 .335 .760,00$ & 19,795 \\
\hline
\end{tabular}

Sumber : BPK-BMD Prov. Sulawesi Utara (Data Diolah)

c. Analisis Belanja Belanja Tak Terduga Terhadap Total Belanja

Analisis belanja tak terduga terhadap total belanja merupakan perbandingan antara total realisasi belanja tak terduga dengan total belanja. Rasio ini memberikan informasi mengenai porsi belanja daerah yang dialokasikan untuk belanja tak terduga pada tahun anggaran bersangkutan.

Rasio Belanja Tak Terduga Terhadap Belanja $=\frac{\text { Total Belanja Tak Terduga }}{\text { Total Belanja }} \times 100 \%$

Tabel 8. Analisis Belanja Tak Terduga Terhadap Total Belanja T.A 2009-2012

\begin{tabular}{crcc}
\hline $\begin{array}{c}\text { Tahun } \\
\text { Anggaran }\end{array}$ & $\begin{array}{c}\text { Total Belanja Tak } \\
\text { Terduga (RP) }\end{array}$ & Total Belanja (RP) & $\begin{array}{c}\text { Rasio Belanja } \\
\text { Tak Terduga } \\
\text { terhadap Total } \\
\text { Belanja (\%) }\end{array}$ \\
\hline 2009 & $2.253 .858 .320,00$ & $1.034 .427 .881 .782,38$ & 0,22 \\
2010 & $1.298 .176 .216,00$ & $1.137 .423 .444 .598,00$ & 0,12 \\
2011 & $799.238 .460,00$ & $1.285 .864 .832 .396,00$ & 0,07
\end{tabular}




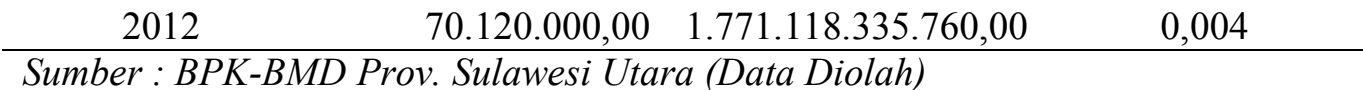

d. Analisis Belanja Transfer Bagi Hasil Ke Kab/Kota Terhadap Total Belanja

Analisis belanja transfer bagi hasil terhadap total belanja merupakan perbandingan antara total realisasi transfer bagi hasil dengan total belanja. Rasio ini memberikan informasi mengenai porsi belanja daerah yang dialokasikan untuk transfer bagi hasil pada tahun anggaran bersangkutan.

$$
\text { Rasio Belanja Transfer Bagi Hasil Terhadap Belanja }=\frac{\text { Total Transfer Bagi Hasil }}{\text { Total Belanja }} \times 100 \%
$$

Tabel 9. Analisis Belanja Transfer Bagi Hasil Terhadap Total Belanja T.A 2009-2012

\begin{tabular}{cccc}
\hline $\begin{array}{c}\text { Tahun } \\
\text { Anggaran }\end{array}$ & $\begin{array}{c}\text { Total Transfer } \\
\text { Bagi Hasil (RP) }\end{array}$ & Total Belanja (RP) & $\begin{array}{c}\text { Rasio Transfer } \\
\text { Bagi Hasil } \\
\text { terhadap Total } \\
\text { Belanja (\%) }\end{array}$ \\
\hline 2009 & $136.687 .892 .418,00$ & $1.034 .427 .881 .782,38$ & 13,21 \\
2010 & $137.100 .431 .295,00$ & $1.137 .423 .444 .598,00$ & 12,05 \\
2011 & $187.539 .904 .485,00$ & $1.285 .864 .832 .396,00$ & 14,58 \\
2012 & $198.156 .413 .252,00$ & $1.771 .118 .335 .760,00$ & 11,188 \\
\hline
\end{tabular}

Sumber : BPK-BMD Prov. Sulawesi Utara (Data Diolah)

\section{Rasio Efisiensi Belanja}

Rasio efisiensi belanja merupakan perbandingan antara realisasi belanja dengan anggaran belanja. Rasio efisiensi belanja ini digunakan untuk mengukur tingkat penghematan anggaran yang dilakukan pemerintah (Mahmudi 2010: 166).

$$
\text { Rasio Eisi ens i Belanja }=\frac{\text { Realisasi Belanja }}{\text { Anggaran Belanja }} \times 100 \%
$$

Tabel 10. Rasio Efesiensi Belanja T.A 2009-2012

\begin{tabular}{cccc}
\hline $\begin{array}{c}\text { Tahun } \\
\text { Anggaran }\end{array}$ & $\begin{array}{c}\text { Realisasi Belanja } \\
(\text { RP) }\end{array}$ & $\begin{array}{c}\text { Anggaran Belanja } \\
(\text { RP) }\end{array}$ & $\begin{array}{c}\text { Rasio Efisiensi } \\
\text { Belanja (\%) }\end{array}$ \\
\hline 2009 & $1.034 .427 .881 .782,38$ & $1.130 .163 .153 .000,00$ & 91,53 \\
2010 & $1.137 .423 .444 .598,00$ & $1.198 .752 .521 .858,00$ & 94,88 \\
2011 & $1.285 .864 .832 .396,00$ & $1.443 .702 .565 .121,00$ & 89,07 \\
2012 & $1.771 .118 .335 .760,00$ & $1.960 .448 .831 .535,00$ & 90,34 \\
\hline
\end{tabular}

Sumber : BPK-BMD Prov. Sulawesi Utara (Data Diolah)

\section{Rasio Belanja Daerah terhadap PDRB (Product Domestic Regional Bruto)}

Rasio belanja terhadap PDRB merupakan perbandingan antara total belanja daerah dengan PDRB yang dihasilkan daerah. Rasio menunjukan produktivitas dan efektivitas belanja darah (Mahmudi 2010: 165).

$$
\text { Rasio Belanja Daerah thd PDRB }=\frac{\text { Total Realisasi Anggaran }}{\text { Total PDRB }} \times 100 \%
$$

Tabel 11. Rasio Efesiensi Belanja Daerah Terhadap PDRB T.A 2009-2012

\begin{tabular}{cccc} 
Tahun & Realisasi Belanja & Total PDRB & $\begin{array}{c}\text { Rasio Belanja } \\
\text { Terhadap }\end{array}$ \\
Anggaran & (RP) & (RP) & PDRB (\%) \\
\hline
\end{tabular}




\begin{tabular}{llll}
\hline 2009 & $1.034 .427 .881 .782,38$ & $17.149 .624 .000 .000,00$ & 6,03 \\
2010 & $1.137 .423 .444 .598,00$ & $18.371 .201 .000 .000,00$ & 6,19 \\
2011 & $1.285 .864 .832 .396,00$ & $19.735 .437 .860 .000,00$ & 6,52 \\
2012 & $1.771 .118 .335 .760,00$ & $21.286 .578 .380 .000,00$ & 8,32 \\
\hline
\end{tabular}

Sumber : BPK-BMD Prov. Sulawesi Utara (Data Diolah)

Pembahasan

Analisis Varians (Selisih) Angagaran Belanja

Berdasarkan tabel 2 kita dapat mengambil kesimpulan. Bahwa pada tahun anggaran 2009 terdapat selisih anggaran belanja dengan realisasi yang bersaldo negatif, yang menunjukan adanya efesiensi atau penghematan anggaran belanja sebesar Rp. 95.735.271.217,62 atau sebesar 8,47\% dari total belanja APBD. Pada tahun anggaran 2010 selisih anggaran belanja sebesar Rp. 61.329.077.260,00 atau sebesar 5,12\% dari total belanja APBD. Pada tahun anggaran 2011 selisih anggaran belanja sebesar Rp. 157.837.732.725,00 atau sebesar 10,93\% dari total belanja APBD. Pada tahun anggaran 2012 selisih anggaran belanja sebesar Rp. 189.330.495.775,00 atau sebesar 9,66\%.

Analisis Pertumbuhan Belanja

Tabel 12. Tabel Pertumbuhan Realisasi Belanja T.A 2010 - 2012

\begin{tabular}{cccc}
\hline Uraian & $\mathbf{2 0 0 9 - 2 0 1 0}$ & $\mathbf{2 0 1 0 - 2 0 1 1}$ & $\mathbf{2 0 1 1 - 2 0 1 2}$ \\
\hline REALISASI BELANJA & 1.034 .427 .881 .782$, & 1.137 .423 .444 .59 & 1.285 .864 .832 .39 \\
& 38 & 8,00 & 6,00 \\
REALISASI BELANJA & 1.137 .423 .444 .598$, & 1.285 .864 .832 .39 & 1.771 .118 .335 .76 \\
KENAIKAN & 00 & 6,00 & 0,00 \\
(PENURUNAN) & $102.995 .562 .815,6$ & 148.441 .387 .798$, & $485.253 .503,364$, \\
$\%$ & 2 & 00 & 00 \\
& 9,96 & 13,05 & 37,74 \\
\hline
\end{tabular}

Sumber : Tabel 3,4,5 (Data Diolah)

Berdasarkan tabel 12 secara keseluruhan dapat kita lihat terjadi pertumbuhan realisasi anggaran belanja yang signifikan. Total pertumbuhan realisasi belanja pada tahun 2010 adalah sebanyak Rp. 102.995562.815,62 atau sebesar 9,96\% dari dari total realisasi belanja tahun 2009. Total pertumbuhan realisasi belanja tahun 2011 adalah sebanyak 148.441.387.798,00 atau sebesar 13,05\% dari total realisasi belanja tahun 2010. Dan total pertumbuhan realisasi belanja tahun 2012 adalah sebanyak 485.253.503.364,00 atau sebesar 37,74\% dari total realisasi belanja tahun 2011.

Analisis Keserasian Belanja

Tabel 13. Tabel Rasio Keserasian Belanja T.A 2009-2012

\begin{tabular}{cccccc}
\hline $\begin{array}{c}\text { Tahun } \\
\text { Anggaran }\end{array}$ & $\begin{array}{c}\text { Rasio } \\
\text { Belanja } \\
\text { Operasi (\%) }\end{array}$ & $\begin{array}{c}\text { Rasio } \\
\text { Belanja } \\
\text { Modal (\%) }\end{array}$ & $\begin{array}{c}\text { Rasio Belanja } \\
\text { Tak Terduga } \\
(\%)\end{array}$ & $\begin{array}{c}\text { Rasio } \\
\text { Transfer } \\
\text { Bagi Hasil } \\
(\%)\end{array}$ & Total \\
\hline 2009 & 63,24 & 23,33 & 0,22 & 13,21 & 100 \\
2010 & 73,38 & 14,45 & 0,12 & 12,05 & 100 \\
2011 & 67,18 & 18,17 & 0,07 & 14,58 & 100 \\
2012 & 69,013 & 19,795 & 0,004 & 11,188 & 100 \\
\hline
\end{tabular}

Sumber : Tabel 6,7,8,9 (Data Diolah) 
Berdasarkan tabel 13 dapat kita lihat rasio pembagian anggaran belanja. Dimana penggunaan anggaran paling banyak dialokasikan ke belanja operasi yang pada tahun 2009 belanja operasi mendapatkan rasio sebanyak 63,24\%, tahun 2010 sebanyak 73,38\%, tahun 2011 sebenyak 67,18\% dan tahun 2012 sebanyak 69,013\%. Untuk belanja modal rasio pada tahun 2009 sebanyak $23,33 \%$, tahun 2010 sebanyak 14,45\%, tahun 2011 sebanyak 18,17\%, dan tahun 2012 sebnyak 19,795\%. Untuk belanja tak terduga rasio pada tahun 2009 sebanyak 0,22\%, tahun 2010 sebanyak $0,12 \%$, tahun 2011 sebanyak 0,07\%, dan tahun 2012 sebnyak 0,004\%. Untuk transfer bagi hasil rasio pada tahun 2009 sebanyak 13,21\%, tahun 2010 sebanyak 12,05\%, tahun 2011 sebanyak 14,58\%, dan tahun 2012 sebnyak 11,188\%.

\section{Rasio Efisiensi Belanja}

Berdasarkan tabel 10 dapat kita lihat terjadi efisiensi penggunaan anggaran belanja. Tahun 2009 total realisasi belanja hanya sebesar $91,53 \%$ dari total anggaran belanja yang dianggarakan pada APBD. Tahun 2010 total realisasi belanja hanya sebesar 94,88\% dari total anggaran belanja yang dianggarkan pada APBD. Tahun 2011 total realisasi belanja hanya sebesar 89,07\% dari total anggaran belanja yang dianggarkan pada APBD. Tahun 2012 total realisasi belanja hanya sebesar 90,34\% dari total anggaran belanja yang dianggarkan pada APBD.

\section{Rasio Belanja Daerah terhadap PDRB (Product Domestic Regional Bruto)}

Berdasarkan tabel 11 dapat kita simpulkan, untuk T.A 2009 rasio belanja terhadap PDRB adalah sebesar 6,03\%, T.A 2010 sebesar 6,19\%, T.A 2011 sebesar 6,52\% dan untuk T.A 2012 sebesar 8,32\%.

Secara umum hasil analisis kinerja anggaran belanja Pemerintah Provinsi Sulawesi Utara berdasarkan Laporan Realisasi Anggaran pada T.A 2009 sampai dengan 2012 sudah cukup baik. Dimana terjadi efisiensi penggunaan anggaran belanja daerah dan terdapat pertumbuhan anggaran belanja yang wajar dari tahun 2009 sampai 2012.

\section{PENUTUP}

\section{Kesimpulan}

Kesimpulan dari penelitian ini adalah sebagai berikut:

a. Dari analisis varians belanja dapat diketahui bahwa kinerja anggaran belanja Pemerintah Provinsi Sulawesi Utara dari Tahun Anggaran 2009 sampai dengan Tahun Anggaran 2012 menunjukan kinerja yang baik dikarenakan ada hasil negatif yang menunjukan bahwa adanya penghematan penggunaan realisasi anggaran.

b. Dari hasil analisis pertumbuhan belanja Tahun Anggaran 2009/2010, Tahun Anggaran 2010/2011 dan Tahun Anggaran 2011/2012 menunjukan adanya pertumbuhan belanja. Pada tahun 2010 adalah pertumbuhan sebesar 9,96\% Tahun 2011 adalah pertumbuhan sebesar 13,05 $\%$. Tahun 2012 adalah sebesar 37,74\%.

c. Dari hasil analisis keserasian belanja maka dapat diketahui bahwa Pemerintah Provinsi Sulawesi Utara dalam menggunakan aktivitas belanjanya, tidak hanya memfokuskan belanja pada belanja operasi akan tetapi juga kepada belanja modal, belanja tak terduga dan transfer bagi hasil ke $\mathrm{kab} /$ kota.

d. Dari hasil perhitungan rasio efesiensi belanja, maka dapat dilihat mulai Tahun Anggaran 2009 sampai dengan 2012. Pemerintah Provinsi Sulawesi Utara sudah melakukan penghematan anggaran. Pada T.A anggaran 2009 Pemerintah Provinsi melakukan penghematan sebesar $8,47 \%$, T.A 2010 sebesar 5,12\%, T.A 2011 sebesar $10,93 \%$ dan pada T.A 2012 sebesar $9,66 \%$.

e. Rasio belanja daerah terhadap PDRB menunjukan efisiensi belanja yang baik terhadap PDRB. Untuk T.A 2009 rasio belanja terhadap PDRB adalah sebesar 6,03\%, T.A 2010 sebesar 6,19\%, T.A 2011 sebesar 6,52\% dan untuk T.A 2012 sebesar 8,32\%.

f. Secara umum hasil analisis kinerja anggaran belanja Pemerintah Provinsi Sulawesi Utara berdasarkan Laporan Realisasi Anggaran pada T.A 2009 sampai dengan 2012 sudah cukup baik. 
Dimana terjadi efisiensi penggunaan anggaran belanja daerah dan terdapat pertumbuhan anggaran belanja yang wajar dari tahun 2009 sampai 2012.

\section{Saran}

Dari kesimpulan yang ada maka dapat diberikan beberapa saran sebagai berikut:

a. Bagi Badan Pengelola Keuangan dan Barang Milik Daerah agar semakin meningkatkan kinerja dalam pengelola anggaran belanja daerah secara khusus dan APBD secara umum. Dengan kinerja yang baik maka efektivitas, produktivitas, dan efisiensi belanja juga akan semakin baik.

b. Dalam hal keserasian belanja, Pemerintah Provinsi Sulawesi Utara perlu lebih meningkatkan Belanja Modal. Karena belanja modal yang digunakan untuk aset-aset tetap akan berguna dalam jangka panjang yang akan memberikan manfaat pada masa yang akan datang.

c. Kiranya penelitian ini dapat menjadi bahan acuan bagi penelitian selanjutnya, agar dapat meneliti kinerja anggaran belanja secara lebih rinci terhadap Laporan Realisasi Anggaran (LRA). Sehingga akan selalu ada perubahan kearah yang lebih baik.

\section{DAFTAR PUSTAKA}

Darise, Nurlan. 2008. Akuntansi Keuangan Daerah (Akuntansi Sektor Publik). PT.Indeks. Jakarta.

Erlina, Sri Mulyadi. 2007. Metode Penelitian Bisnis Untuk Akuntansi dan Manajemen. USU Press. Medan.

Galaento, Frengky. 2010. Analisis Kinerja Belanja Dalam Laporan Realisasi Anggaran (LRA) Pada Dinas Pendapatan Pengelolaan Keuangan Dan Aset Daerah Di Kabupaten Luwuk Banggai. Skripsi. Universitas Sam Ratulangi. Manado.

Halim, Abdul. 2007. Akuntansi Sektor Publik. Akuntansi Keuangan Daerah. Salemba Empat. Jakarta.

Horngren., Harrison., Oliver. 2009. Accounting Eight Edition. Pearson Education, Inc. New Jersey.

Kuncoro, Mudrajad. 2009. Metode Riset untuk Bisnis dan Ekonomi. Erlangga. Jakarta.

Mahmudi. 2010. Analisis Laporan Keuangan Pemerintah Daerah. Unit Penerbit dan Percetakan STIM YKPN. Yogyakarta.

Mahsun, Muhamad. 2009. Pengukuran Kinerja Sektor Publik. BPFE. Yogyakarta.

Mardiasmo. 2009. Akuntansi Sektor Publik. Andi. Yogyakarta.

Marizka, Addina. 2009. Analisis Kinerja Pengelolaan anggaran Pendapatan dan Belanja Daerah Pemerintah Kota Medan. Skripsi. Universitas Sumatera Utara. Medan. http://repository.usu.ac.id/bitstream/123456789/9556/1/10E00382.pdf Diakses 07 Januari 2014.

Tim Redaksi CV. Tamita Utama, 2011. Standar Akuntansi Pemerintah Tahun 2010. Jakarta.

Tim Penyusun Direktorat Jendral Perimbangan Keuangan, 2013. Modul Belanja Daerah - Kursus Keuangan Daerah (KKD) 2013. Jakarta. 